\title{
IMPLEMENTASI MANAJEMEN PENDIDIK DAN TENAGA KEPENDIDIKAN BERBASIS SEKOLAH DALAM PENINGKATAN MUTU SEKOLAH DASAR DI KOTA BEKASI
}

\author{
Neti Karnati \\ Fakultas Ilmu Pendidikan, Universitas Negeri Jakarta \\ Email: karnateneti19@yahoo.co.id
}

\begin{abstract}
The research aims to analyze the implementation of Educator and Education Personnel Management School-Based in improving the quality of Elementary School in the district of North Bekasi.Bekasi City. Quantitative research approach and survey research method. Place of study at State Elementary School in District of North Bekasi. The number of research population is 49 public Elementary School and 35 research samples of public elementary school. The results of the research are: (a) Implementation in the planning needs of Educators and education personnel has been very good, because, as many as 26 schools (74\%) are very good, 7 schools (20\%) good and 2 schools (6\%) enough. (b) Implementation in organizing Educators and Education Personnel Public elementary school has been very good because as many as 23 schools (66\%) very good, 12 schools (34\%) good. (c) Implementation in the development and development of Primary School Educators and Education Personnel has been very good because, as many as 28 schools (80\%) very good, 7 schools (20\%). (d) Implementation in the supervision and performance assessment of School Educators and Education Personnel has been very good, because as many as 30 schools (86\%) very good, 5 schools (24\%) good. (e) Implementation in Dismissal of Primary School Teachers and Education Personnel is good because, as many as 8 schools (23\%) very good, 23 schools (65\%) good and 4 schools (12\%) enough The implication of this research is that the Implementation of Educator and Education Personnel Management public elementary schools that have been very good need to be maintained. The good implementation of Educators and Education Personnel Management can improve their performance increases. The performance of educators and education personnel is expected to improve the quality of education in primary schools.
\end{abstract}

Keywords: Management, Educators and Education Personnel, planning, organizing, coaching and development, supervision and dismissal.

\begin{abstract}
Abstrak
Penelitian ini bertujuan untuk menganalisis pelaksanaan Manajemen Pendidik dan Kependidikan Berbasis Sekolah dalam meningkatkan mutu Sekolah Dasar di Kecamatan Bekasi Utara, Kota Bekasi. Pendekatan penelitian kuantitatif dan metode penelitian survei. Tempat studi di Sekolah Dasar Negeri di Kabupaten Bekasi Utara. Jumlah populasi penelitian adalah 49 siswa SD dan 35 sampel penelitian sekolah dasar negeri. Hasil penelitian tersebut adalah: (a) Implementasi dalam perencanaan kebutuhan pendidik dan tenaga kependidikan sudah sangat baik, karena sebanyak 26 sekolah (74\%) sangat baik, 7 sekolah (20\%) baik dan 2 sekolah (6\%) cukup baik. (b) Pelaksanaan pengorganisasian pendidik dan tenaga kependidikan sekolah dasar negeri sudah sangat baik karena sebanyak 23 sekolah (66\%) sangat baik, 12 sekolah (34\%) baik. (c) Implementasi dalam pengembangan dan pengembangan Pendidik Sekolah Dasar dan Tenaga Kependidikan sudah sangat baik karena, sebanyak 28 sekolah (80\%) sangat baik, 7 sekolah (20\%) baik. (d) Implementasi dalam supervisi dan penilaian kinerja Pendidik Sekolah dan Tenaga Kependidikan sudah sangat baik, karena sebanyak 30 sekolah (86\%) sangat baik, 5 sekolah (24\%) baik. (e) Pelaksanaan pemberhentian guru sekolah dasar dan tenaga kependidikan baik karena sebanyak 8 sekolah (23\%) memiliki kategori sangat baik, 23 sekolah $(65 \%)$ baik dan 4 sekolah (12\%) cukup . Implikasi dari penelitian ini adalah bahwa implementasi Manajemen Pendidik dan Kependidikan Sekolah Dasar Negeri yang selama ini sangat dibutuhkan harus dijaga. Penerapan Manajemen Pendidik dan Tenaga Kependidikan yang baik dapat meningkatkan kinerja pendidik dan tenaga kependidikan. Kinerja pendidik dan tenaga kependidikan dapat meningkatkan kualitas pendidikan di sekolah dasar.
\end{abstract}


Kata kunci: Manajemen, Pendidik dan Tenaga Kependidikan, perencanaan, pengorganisasian, pembinaan dan pengembangan, pengawasan dan pemberhentian.

\section{PENDAHULUAN}

Manajemen Berbasis Sekolah (MBS) merupakan bagian dari strategi pemerintah dalam rangka meningkatkan mutu pendidikan melalui desentralisasi pendidikan. Penerapan MBS diharapkan dapat memperkuat kehidupan demokratisasi, desentralisasi kewenangan, sumber daya, dan dana di tingkat sekolah. Setelah lebih dari satu dasawarsa, sejak Manajemen Berbasis Sekolah (MBS) dirintis dan diterapkan, pencapaian keberhasilannya di sekolah sangat variatif. Banyak sekolah yang berhasil menerapkan MBS dengan baik, tetapi masih banyak pula sekolah yang kurang berhasil. Sesuai dengan Rencana Strategis Kementerian Pendidikan dan Kebudayaan Tahun 2010 s.d. 2014, diharapkan pada akhir Tahun 2014, 90\% sekolah telah menerapkan MBS dengan baik. Berkenaan dengan hal tersebut, upaya peningkatan jumlah sekolah yang dapat menerapkan MBS dengan baik perlu segera dilaksanakan.

Keberhasilan penerapan MBS di Sekolah Dasar (SD) masih beragam. Berdasarkan penelitian dan pengamatan tentang MBS, keberagaman keberhasilan tersebut disebabkan antara lain belum kuatnya komitmen pengambil kebijakan pendidikan di daerah (baik tingkat Provinsi maupun Kabupaten/Kota), selain itu kurangnya pemahaman pihak sekolah akan makna dan signifikansi penerapan Manajemen Berbasis Sekolah dalam peningkatan mutu sekolah, yang berimplikasi Manajemen Berbasis Sekolah (MBS) belum dapat berjalan secara baik. (Kemendikbud, 2014:1)

Untuk itu, walaupun konsep Manajemen Berbasis Sekolah sebagai model pengelolaan sekolah telah lama disosialisasikan, dirintis penerapannya dan telah dilaksanakan, tetapi perlu dilakukan penyegaran dan digiatkan kembali pelaksanaannya. Bagi sekolah yang telah berhasil melaksanakan dengan baik, perlu meningkatkan diri dan menjaga keberlanjutannya. Sedangkan bagi sekolah yang belum optimal menerapkan atau bahkan baru melaksanakan MBS, perlu didorong dan dibuka wawasannya tentang makna dan pentingnya MBS bagi upaya perbaikan kualitas pendidikan di lingkup sekolah, daerah, maupun nasional.

Keberhasilan implementasi MBS dapat mencakup berbagai bidang manajemen sekolah. Bidang-bidang Manajemen Berbasis Siswa (MBS) meliputi: manajemen peserta didik, kurikulum, peran serta masyarakat, keuangan/pembiayaan, pendidik dan tenaga kependidikan, sarana dan prasarana sekolah, sistem informasi manajemen.

Manajemen pendidik dan tenaga kependidikan pada sekolah dasar baik negeri dan swasta masih perlu ditingkatkan. Adanya manajemen PTK yang efektif dan efisien pada sekolah dasar, akan berdampak pada meningkatnya kinerja PTK yang ada di sekolah. Pendidik dan Tenaga Kependidikan pada SD negeri di Bekasi cenderung banyak masalah. Masalah PTK di Bekasi sangat beragam, seperti: masih rendahnya kesejahteraan, kurangnya jumlah guru dan tenaga kep masih pendidikan, serta tingginya beban kerja PTK. Tenaga kependidikan pada sekolah menurut Standar Nasional Pendidikan dapat terdiri dari: tenaga administrsi sekolah (TAS), pustakawan sekolah, laboran, dan teknisi sekolah. Pada kenyataannya pada sekolah dasar negeri jenis tenaga kependidikan masih sangat kurang.

Seperti yang disampaikan oleh Kepala Dinas Pendidikan Kota Bekasi sebagai berikut:

(Disdik) Kota Bekasi bakal kehilangan ratusan guru berstatus pegawai negeri sipil (PNS) diwilayahnya. Pasalnya, ratusan guru tersebut akan memasuki masa pensiun pada tahun 2015. Artinya, tahun depan Kota 
Bekasi akan kukurangan guru. Kepala Dinas Pendidikan (Kadisdik) Kota Bekasi, Rudi Sabarudin mengatakan, ratusan guru yang pensiun ditahun ini mayoritas guru sekolah dasar. Kebanyakan tenaga pendidik itu pensiun lantaran umurnya sudah masuk usia 60 tahun. "Totalnya sebanyak 110 guru," kata Rudi kepada wartawan di Bekasi, Senin 29 Juni 2015. Menurut Rudi, berdasarkan Undang-undang aparatur sipil negara, otomatis masa kerja mereka tak bisa diperpanjang. Karena sudah ada tambahan selama dua tahun sebelumnya ketika usia 58 tahun. (Dinas Pendidikan Kota Bekasi, 2016)

Hal ini menunjukkan beban guru SD Negeri di Kota Bekasi menjadi semakin berat sehingga berlebih karena kurangnya guru.

$$
\text { Banyaknya masalah yang }
$$

berhubungan dengan Pendidik dan Tenaga Kepen-didikan (PTK) di Sekolah dasar Negeri di Kota Bekasi ini, maka mengharuskan para kepala sekolah mengimplementasikan manajemen Pendidik dan Tenaga Kependidikan yang efektif dan efisien. Dengan segala fasilitas yang dimiliki di sekolah, kepala sekolah seoptimal mungkin harus mengelola sekolah yang berbasis sekolah pada semua bidang. Dengan demikian selanjutnya, peneliti tertarik untuk meneliti bagaimana implementasi manajemen pendidik dan tenaga kependidikan berbasis sekolah di sekolah dasar negeri Kota Bekasi.

\section{METODOLOGI PENELITIAN}

Tujuan umum penelitian ini adalah: ingin menganalisis implementasi manajemen pendidik dan kependidikan berbasis sekolah dalam peningkatan mutu sekolah dasar negeri di kecamatan Bekasi Utara, Kota Bekasi. Penelitian ini dilakukan di lingkungan Dinas Pendidikan Kota Bekasi Jawa Barat. Dengan sasaran penelitian adalah Sekolah Dasar Negeri. Waktu penelitian selama 10 bulan mulai dari penyusunan proposal, penyusunan intrumen penelitian, pengumpulan data, analisis data sampai penyusunan laporan hasil penelitian.
Mulai bulan Pebruari sampai dengan November 2017.

Pendekatan penelitian yang digunakan adalah pendekatan kuantitatif dengan metode survei. Analisis data menggunakan analisis deskriptif dengan statistik sederhana. Populasi dalam penelitian adalah seluruh sekolah dasar negeri sebanyak 49 sekolah di Kecamatan Bekasi Utara, Kota Bekasi. Sedangkan sampel penelitian diambil sebanyak 35 sekolah dengan menggunakan teknik pengambilan sample adalah simple random sampling.

\section{HASIL DAN PEMBAHASAN}

Dari 35 sekolah dasar negeri yang menjadi sampel dari penelitian ini dapat diketahui jumlah guru secara keseluruhan sebanyak 650 orang dengan rincian sebagai pendidik dengan stutus Pegawai Negeri Sipil (PNS) sebanyak 376 orang (59\%) sedangkan yang berstatus Non PNS baik sebagai TKK (Tenaga Kerja Kontrak) maupun sukwan sebanyak 274 orang (41\%). Dengan demikian pada Sekolah dasar Negeri di Kecamatan Bekasi Utara masih memiliki banyak guru honorernya. Adanya perbedaan status kepegawaian diantara para pendidik atau guru ini dapat berdampak negatif pada kinerja guru. Untuk menghindari dampak negatif tersebut, maka Kepala sekolah harus berusaha melakukan manajemen secara professional pada pendidik dan tenaga kependidikan.

Dari sebanyak 35 sekolah jumlah jenis tenaga kependidikan yang ada pada sekolah bervariasi. Tenaga kependidikan yang sebaiknya ada di sekolah dasar yaitu: operator sekolah, staf tata usaha sekolah, tenaga keamanan atau penjaga sekolah dan pustakawan sekolah. Terdapat sekolah yang belum memiliki tenaga operator sekolah sebanyak 25 sekolah (71\%), ada 9 sekolah (26\%) yang memiliki 1 orang tenaga operator sekolah, ada 1 sekolah (3\%) yang memiliki 2 orang tenaga operator sekolah. Dengan demikian masih banyak sekolah dasar yang belum memiliki operator sekolah. 
Tetapi pada umumnya operator sekolah dari beberapa sekolah dirangkap oleh staf tata usaha sekolah yang ada.

Tenaga staf administrasi atau tata usaha sekolah pada sekolah dasar yang menjadi sampel penelitian diperoleh data sebagai berikut: terdapat 5 sekolah (14\%) yang tidak memiliki tenaga tata usaha, 24 sekolah $(69 \%)$ yang memiliki 1 orang, ada 3 sekolah $(8,5 \%)$ memiliki 2 orang, dan ada 3 sekolah $(8,5 \%)$ yang memiliki 3 orang tanaga tata usaha sekolah. Dengan demikian pada sekolah yang belum memiliki tenaga administrasi sekolah harus segera diangkat tenaga administrasi sekolah atau tata usaha sekolah.

Penjaga/keamanan sekolah secara umum setiap sekolah sudah memiliki tenaga penjaga sekolah. Secara rinci dapat diuraikan sebagai berikut: terdapat 1 sekolah (3\%) tidak memiliki penjaga sekolah, ada 27 sekolah $(76 \%)$ memiliki 1 orang penjaga sekolah, terdapat 5 sekolah (15\%) yang memiliki 2 orang panjaga sekolah, ada 1 sekolah (3\%) yang memiliki 3 orang penjaga sekolah dan ada 1 sekolah (3\%) yang memiliki 4 orang penjaga. Bedasarkan data kepegawaian bulan April 2017 yang ada pada kantor UPTD Pembinaan SD Kecamatan Bekasi Utara secara umum tenaga kependidikan yang ada hampir $96 \%$ mereka berstatus honorer atau Non PNS.

Tenaga pustakawan sekolah dasar dari semua sekolah yang diteliti tidak ada satu sekolahpun yang memiliki tenaga pustakawan sekolah. Hal ini terdapat beberapa alasan salah satunya ruang perpustakaan pada sekolah secara umum dikelola oleh guru yang ada.

\section{Perencanaan Kebutuhan Pendidik dan} Tenaga Kependidikan berbasis sekolah sebagai upaya peningkatan mutu sekolah.

Perencanaan kebutuhan pendidik dan tanaga kependidikan sekolah merupakan salah satu kegiatan yang harus dilakukan pada manajemen PTK. Hasil penelitian menunjukan implementasi dalam perencanaan kebutuhan PTK di Sekolah dasar Negeri Kecamatan Bekasi
Utara, maka diuraikan hasil evaluasi sebagai berikut: telah melakukan perencanaan kebutuhan PTK sebanyak 26 sekolah (74\%) dengan kategori sangat baik, 7 sekolah (20\%) dengan kategori baik dan 2 sekolah ( $6 \%$ ) dengan kategori cukup. Berdasarkan data tersebut di atas dapat disimpulkan bahwa secara umum sekolah dasar negeri di Kecamatan Bekasi Utara sudah mengimplemen-tasikan perencanaan kebutuhan PTK dengan berhasil.

2. Pengorganisasian Pendidik dan Tenaga Kependidikan berbasis sekolah sebagai upaya peningkatan mutu sekolah.

Pengorganisasian pendidik dan tenaga kependidikan sekolah merupakan salah satu kegiatan yang harus dilakukan pada manajemen PTK. Hasil penelitian menunjukan implementasi dalam pengorganisasian PTK di Sekolah dasar Negeri Kecamatan Bekasi Utara, maka diuraikan hasil evaluasi sebagai berikut: telah melakukan pengorganisasian PTK sebanyak 23 sekolah (66\%) dengan kategori sangat baik, 12 sekolah ( 34\%) dengan kategori baik.

Dengan demikian dapat disimpulkan bahwa pengorganisasian PTK pada sekolah dasar di kecamatan Bekasi Utara sudah dilaksanakan dengan sangat baik sebagian besar. Pengorganisasian yang sudah dilaksanakan dengan baik akan menghasilkan kinerja para PTK pada sekolah tersebut akan meningkat. Kinerja PTK yang baik selanjutnya dapat berdampak baik pada peningkatan mutu pendidikan pada sekolah yang bersangkutan.

3. Pembinaan dan pengembangan PTK berbasis sekolah sebagai upaya peningkatan mutu Sekolah Hasil penelitian dalam implementasi dalam pembinaan dan pengembangan PTK di Sekolah dasar Negeri Kecamatan Bekasi Utara, maka diuraikan hasil evaluasi sebagai berikut: telah melakukan pembinaan dan pengembangan PTK sebanyak 28 sekolah 
(80\%) dengan kategori sangat baik, 7 sekolah (20\%) dengan kategori baik dan 0 sekolah ( $0 \%$ ) dengan kategori cukup.

Dengan demikian dapat disimpulkan bahwa pembinaan dan pengembangan PTK pada sekolah dasar di kecamatan Bekasi Utara sudah dilaksanakan dengan sangat baik sebagian besar. Pembinaan dan pengembangan PTK yang sudah dilaksanakan dengan baik akan menghasilkan kinerja para PTK pada sekolah tersebut akan meningkat. Pembinaan pada PTK bertujuan unutk membantu para PTK jika mereka mengalami kesulitan dalam bekerja. Pembinaan pada para PTK sekolah dapat dilakukan melalui kegiatan pelatihan atau pemberian saran kerja yang lebih baik. Sedangkan pengembangan pada para PTK sekolah bertujuan untuk meningkatkan kinerja para PTK sekolah yang sudah baik agar bisa lebih baik lagi atau minimal tetap. Kinerja PTK yang baik selanjutnya dapat berdampak baik pada peningkatan mutu pendidikan pada sekolah yang bersangkutan.

\section{Pengawasan dan penilaian kinerja} PTK berbasis sekolah sebagai upaya peningkatan mutu Sekolah

Pengawasan terhadap kinerja PTK merupakan suatu proses pengamatan terhadap perilaku kerja para PTK sekolah untuk mengetahui kelebihan dan kekurangan dari perilaku kerja PTK sekolah.

Hasil penelitian menunjukan implementasi dalam pengawasan dan penilaian kinerja PTK di Sekolah dasar Negeri Kecamatan Bekasi Utara, maka diuraikan hasil evaluasi sebagai berikut: telah melakukan pengawasan dan penilaian kinerja PTK sebanyak 30 sekolah $(86 \%)$ dengan kategori sangat baik, 5 sekolah (24\%) dengan kategori baik dan 0 sekolah ( $0 \%$ ) dengan kategori cukup.

Dengan demikian dapat disimpulkan bahwa pengawasan dan penilaian kinerja
PTK pada sekolah dasar di kecamatan Bekasi Utara sudah dilaksanakan dengan sangat baik sebagian besar. Pengawasan dan penilaian kinerja PTK yang sudah dilaksanakan dengan baik akan menghasilkan kinerja para PTK pada sekolah tersebut akan meningkat.

5. Pemberhentian PTK berbasis sekolah sebagai upaya peningkatan mutu sekolah.

Pemberhentian PTK sekolah maksudnya adalah pemutusan hubungan kerja pada suatu sekolah terhadap PTK sekolah. Pada sekolah terdapat dua jenis status kepegawaian PTK, yaitu ada yang berstatus PNS (Pegawai Negeri Sipil atau ASN) dan non PNS (honorer). Batas usia pensiun untuk guru PNS adalah 65 tahun, Sedangkan untuk tenaga Kependidikan PNS adalah 58 tahun.

Hasil penelitian menunjukan implementasi dalam pember-hentian PTK di Sekolah dasar Negeri Kecamatan Bekasi Utara, maka diuraikan hasil evaluasi sebagai berikut: telah melakukan pengawasan dan penilaian kinerja PTK 8 sekolah $(23 \%)$ dengan kategori sangat baik, 23 sekolah (65\%) dengan kategori baik dan 4 sekolah (12\%) dengan kategori cukup.

Dengan demikian dapat disimpulkan bahwa pemberhentian PTK pada sekolah dasar di kecamatan Bekasi Utara sudah dilaksanakan dengan baik sebagian besar. Pemberhentian PTK yang sudah dilaksanakan dengan baik akan mengurangi dampak negatif dari adanya pemberhentian kerja terhadap PTK yang diberhentikan.

6. Buku-buku Kegiatan Manajemen Pendidik dan Tenaga Kependidikan yang dimiliki sekolah

Dalam pelaksanaan Manajemen Pendidik dan tenaga Kependidikan berbasis sekolah terdapat 25 jenis dokumen yang harus dimiliki oleh setiap sekolah dasar. Dari 25 jenis dokumen yang dimiliki oleh sekolah dasar negeri yang menjadi sasaran penelitian, secara 
umum terdapat beberapa dokumen tidak dimiliki secara lengkap ke 25 jenis dokumen di bawah ini. Buku-buku yang dapat dipergunakan untuk menunjang implementasi Manajemen Pendidik dan Tenaga Kependidikan Sekolah adalah sebagai berikut:

1) Buku Laporan umum manajemen pendidik dan tenaga kependidikan

2) Format Usulan Pengadaan Pegawai dan Tenaga Kependidikan

3) Format/Buku Usul Pengangkatan CPNS

4) Buku Daftar Presensi Pendidik dan Tenaga Kependidikan

5) Buku Rekapitulasi Absensi Pendidik dan Tenaga Kependidikan

6) Buku Rencana Kebutuhan Pendidik dan Tenaga Kependidikan

7) Buku Usulan Pengadaan Pendidik dan Tenaga Kependidikan

8) Buku Data Pendidikan dan Tenaga Kependidikan

9) Buku Rekapitulasi Pendidik dan Tenaga Kependidikan menurut Statusnya

10) Buku Rekapitulasi Pendidik dan Tenaga Kependidikan menurut Tempat SK Pengangkatan

11) Buku Rekapitulasi Pendidik dan Tenaga Kependidikan yang Mengikuti Kegiatan Pengembangan Pegawai (Seminar, Lokakarya, Pendidikan dan Pelatihan, Diskusi, Penataran, atau lainnya)

12) Buku Kartu Pribadi/Riwayat Pendidik dan Tenaga Kependidikan

13) Daftar Susunan Keluarga

14) Buku Cuti Pendidik dan Tenaga Kependidikan

15) Format Usul Kenaikan Gaji

16) Buku Catatan Penilaian PNS/DP3

17) Format Daftar Usul Penetapan Angka Kredit

18) Daftar Urut Kepangkatan PNS

19) Format Surat Permintaan Berhenti dari Calon Pegawai Negeri Sipil/Pegawai Negeri Sipil dengan Hak Pensiun
20) Format Surat Pemintaan Pensiun Pegawai Negeri Sipil

21) Format Surat Permintaan Pembayaran Pensiun Pertama

22) Format Surat Pengaduan Permohonan Pensiun Bekas Pegawai Negeri Sipil/Permohonan Pembayaran Pensiun

23) Format Surat Pengaduan untuk Pensiun Janda/Duda

24) Buku Daftar Susunan Keluarga

25) Papan Kegiatan Kepala Sekolah

$\begin{gathered}\text { Dengan demikian setiap sekolah } \\ \text { mampu melengkapi }\end{gathered}$
sebaiknya don dokumen
ketersediaan buku-buku dan dokn
lainnya yang digunakan untuk manajemen
Pendidik dan Tenaga Kependidikan
sekolah. Setiap sekolah dasar perlu da
tenaga adminsitrasi sekolah. Tenaga
adminsitrasi sekolah dapat membantu
kepala sekolah membenahi administrasi
sekolah dengan baik. Manajemen
pendidik dan tenaga kependidikan
sekolah perlu dilakukan secara
profesional untuk meningkatkan mutu
sekolah.

\section{PENUTUP}

A. Simpulan

Manajemen Pendidik dan Tenaga Kependidikan berbasis sekolah di Sekolah dasar Negeri Kecamatan Bekasi Utara sebagian besar sudah diimplentasikan dengan sangat baik dan sebagian kecil baik. Kegiatan Manajemen Pendidik dan Tenaga Kependidikan yang diteliti meliputi kegiatan sebagai berikut: (a) Perencanaan kebutuhan PTK, (b) Pengorganisasian PTK (c) Pembinaan dan pengembangan PTK, (d) Pengawasan dan penilaian kinerja PTK di Sekolah dasar Negeri Kecamatan Bekasi Utara, (e) Pemberhentian PTK. Manajemen PTK yang baik dapat meningkatkan kinerja PTK dan akhirnya dapat meningkatkan mutu sekolah. 
Jurnal Parameter Volume 29 No. 2

DOI : doi.org/10.21009/parameter.292.06

P-ISSN : 0216-26IX

\section{DAFTAR PUSTAKA}

Badriyah, Mila. 2015. Manajemen Sumber Daya Manusia. Bandung: Pustaka Setia.

Dessler, Gary. 2007. Manajemen Sumber Daya Manusia. Jakarta: Indeks

Dessler, G. 1991. Personnel/Human Resources Management. Englewood Cliffs, New Jersey: Printice Hall.

Departemen Pendidikan Nasional, Manajemen Peningkatan Mutu Berbasis Sekolah, Buku I Konsep dan Pelaksanaannya, Jakarta: Direktorat SLP Dirjen Dikdasmen, 2001.

Geet, et al. 2009. Human Resource Management. Chennai: Nirali Prakashan

Gorton, R. A. and Schnelder, G. T. 1991. School Based Leadership: Challenges and Opportunities (Third Edition). New York: WCB Publisher.

Hasibuan, Malayu. 2011. Manajemen Sumber Daya Manusia. Jakarta: Bumi Aksara.

Kreitner \& Kinicki. 2014. Organizational Behavior. New York: McGraw Hill

Mulyasa, Manajemen Berbasis Sekolah: Konsep, Strategi, dan Implementasi, cet. vii, Bandung: Rosdakarya, 2004.

Nurkholis, Manajemen Berbasis Sekolah: Teori, Model, dan Aplikasi, cet. III, Jakarta: Grasindo, 2012.

Nurul Ulfatin - Teguh Triwiyanto. 2016. Manajemen Sumber Daya Manusia Bidang Pendidikan. Jakarta: PT. Raja Grafindo Jakarta
Owens, R. G. 2010. Organizational Behavior Education. Boston: Allyn and Bacon, Inc.

Peraturan Menteri Pendidikan Nasional Republik Indonesia Nomor 16 Tahun 2

Tentang Standar Kualifikasi Akademik dan Kompetensi Guru. Jakarta: Badan Standar Nasional Pendidikan.

Peraturan Menteri Pendidikan Nasional Nomor Nomor 19 Tahun 2007 tentang Standar Pengelolaan untuk Satuan Pendidikan Dasar dan Menengah. Jakarta: Badan Standar Nasional Pendidikan.

Peraturan Menteri Pendidikan Nasional Republik Indonesia Nomor 24 Tahun 2008 Tentang Standar Tenaga Administrasi Sekolah/Madrasah. Jakarta: Badan Standar Nasional Pendidikan.

Sutrisno, Edy. 2014. Manajemen Sumber Daya Manusia. Jakarta: Kencana Media Group.

Syaifuddin, Mohammad, dkk. Manajemen Berbasis Sekolah, Bahan Ajar Cetak, Jakarta: Departemen Pendidikan Nasional, 2007.

UU No. 23 Tahun 2003 tentang Sistem Pendidikan Nasional.

Uno, Hamzah. 2011. Profesi Kependidikan. Jakarta: Bumi Aksara.

Veithzal Rivai. 2009. Manajemen Sumber Daya Manusia untuk Perusahaa. Jakarta: PT. Raya Persada.

Weber, C. A. 2000. Personnel Problem of School Administrators. New York: McGraw-Hill Book Company, Inc. 